\title{
NON-GOVERNMENTAL ORGANISATIONS (NGOS) AND DIMENSIONS OF SUSTAINABLE DEVELOPMENT IN THE ASIA-PACIFIC REGION
}

\author{
Trevor Parfitt
}

\begin{abstract}
This paper examines the role that Non-Governmental Organisations (NGOs) can play in promoting sustainable development in the Asia-Pacific region. It focuses on two dimensions of sustainability, these being sustainability of the development effects of projects and programmes run by development NGOs and environmental sustainability. It is noted that NGOs are thought to have a comparative advantage in pursuing these goals due to their extensive experience working at the grass roots and their relations with local people. Such qualities are seen as conducive to success at delivering sustainable projects and as making NGOs effective advocates for reform of environmental policies. A variety of case studies drawn from across the region are used to demonstrate that NGOs have the capacity to deliver progress with regard to both aforementioned dimensions of sustainability. However, this must be done in collaboration with other concerned parties including the state, international actors and civil society.
\end{abstract}

Keywords: Non-governmental organisations; sustainable development; Asia-Pacific

\section{NGOS AND DIMENSIONS OF SUSTAINABLE DEVELOPMENT IN THE ASIA-PACIFIC REGION}

This paper examines the prospects for Non-Governmental Organisations (NGOs) to play a significant role in promoting sustainable development, particularly in the AsiaPacific region. Their effectiveness with reference to two crucial dimensions of sustainability will be analysed. Firstly, NGO capabilities to produce lasting development effects through their projects and programmes will be assessed. Secondly, it will address their capacity as promoters of environmentally sustainable development, which entails addressing NGO abilities to pursue advocacy strategies, lobbying governments and international agencies to embrace policies that preserve the environment. This will enable us to make some observations on the role that NGOs can play in promoting both these dimensions of sustainability in the Asia-Pacific.

Any observer of international affairs is aware of the massive growth in the number of NGOs that has taken place over the last fifty years. According to one estimate the number of development-oriented NGOs registered in the industrialized Northern states "grew from 1,600 in 1980 to 2,970 in 1993."1 World numbers of NGOs expanded from 28.900 in 1993 to 35,000 by the end of that decade. ${ }^{2}$ With this expansion in numbers has come enhanced influence and most analysts would agree that NGOs have emerged as prominent and influential players in our increasingly 
globalised international system. Some see them as a force for good, one of the best known statements of this ilk being that of former United Nations Secretary General, Kofi Annan who described NGOs as "indispensable partners of the United Nations" and "the conscience of the world." 3 Not all analysts are such unqualified admirers as Annan, one such being Harvey who argues that NGO aid often acts like a Trojan horse for the neo-liberal market policies that are deeply unpopular in many parts of the Global South. ${ }^{4}$

What is clear is that NGOs have become a major force in the field of development. Clark observes that NGOs doubled their real resources in the decade from the mid-seventies to the mid-eighties, mainly due to increasing official contributions. By 1989, Northern NGOs were in charge of US\$6.4 billion of aid to the Global South ${ }^{5}$ and Pieterse notes that by 1997, the development funds channeled through NGOs exceeded the total annual disbursements of the IMF and the World Bank. ${ }^{6}$ A more recent estimate suggests that about US\$8 billion or 15 percent of all development aid is disbursed via NGOs. ${ }^{7}$

Various reasons may be cited for the increasing influence of NGOs as development agents. Some analysts argue that NGO reliance on voluntary staff who are largely motivated by idealism rather than pecuniary incentives makes them more efficient (both financially and in terms of effectiveness) than the often bloated and inefficient state bureaucracies to be found in many parts of the South. It has also been suggested that the greater value commitment of NGO personnel makes them far more effective at working with the poor at the grass roots than the more hierarchical and staid bureaucratic approach of most official Northern aid agencies. Similarly, it has been argued that the greater linkages NGOs have at the grass roots makes them more responsive than other agencies to changing, sometimes volatile conditions on the ground, as well as endowing them with greater awareness of the real needs and demands of the local poor. In this sense they are often seen as being more accountable to ordinary people than many governments that may be openly authoritarian or only dubiously democratic.

Such considerations have led many Northern agencies to see NGOs as the most appropriate vehicles through which to pursue governance programmes that aim to enhance transparent, democratic and efficient government in Southern states. ${ }^{8}$ The latter role entails NGOs being seen not just as efficient conduits for project aid, but also as effective campaigning organizations with a policy advocacy function that entails lobbying government for greater transparency and associated reforms. In the following sections we shall assess how far these contentions hold true with regard to the developmental and environmental dimensions of sustainability.

\section{THE DEVELOPMENTAL DIMENSION OF SUSTAINABILITY}

Firstly, we shall address the question as to how far NGOs have a comparative advantage in undertaking projects that will have sustainable effects. Traditional official sources of aid have always been criticized because all too often their projects tended to collapse shortly after the aid donor ceased to fund them. Thus, health centres, schools and other developmental outputs would function adequately just so long as the funding agency took a direct interest in them, but all too often would deteriorate, sometimes becoming completely moribund when the agency withdrew. 
The author's contacts with numerous development operatives elicited the widely held view that if one visited the site of a project five or more years after withdrawal of the donor and its funding, it was common to find no sign that a project had ever taken place there. In other words, many of the development projects funded through official aid failed the first dimension of sustainability because they did not sustain their developmental outputs.

By contrast with this the linkages NGOs are thought to enjoy at the Southern grass roots enable them to produce sustainable outputs in the following ways. Farrington and Lewis observe that NGO "respect for self-determination encourages them to support the establishment of mechanisms and grassroots organizations through which the rural poor can express views on their needs, and that their small scale and flexibility allow rapid response to these needs." areas where NGOs are thought to be advantaged over official donors. Firstly, their access to the local people endows them with local knowledge of the actual problems of the poor. Secondly, their flexibility enables them to respond to such problems appropriately and with alacrity. Thirdly, their value commitment to helping the poor attain self-determination prompts them to contribute to the development of local social infrastructure that enhances capacity for local people to become involved in development. This latter point links to the participatory tradition of development, which many NGOs have embraced. The leitmotif of the participatory approach is to mobilize people to become directly involved in the development projects that affect them, possibly even formulating and implementing their own projects. All of these factors advantage NGOs in producing sustainable projects. Local knowledge enables them to formulate projects that are more relevant to the interests and needs of local people by contrast with projects sponsored by official agencies, which are often the creation of distant experts who may have little direct knowledge of the conditions experienced by the beneficiaries of their projects. NGO flexibility renders them better able to quickly and efficiently respond to popular needs than the more conservative bureaucracies of states and official agencies. Finally, the NGO propensity to promote local participation and development of local organizations builds the capacity of grass roots communities to take a direct role in implementing and managing projects. If local knowledge enables NGOs to produce more relevant projects local people are more likely to want to preserve them (or take ownership of them to use the terminology favoured by many development workers), whilst participation raises local capacity to sustain them.

An example that goes some way to illustrating how this approach can work is provided by the Citizen's Participation in Local Governance (CPLG) programme, which is sponsored by the British NGO One World Action with funding from the UK Department for International Development (DFID) and coordinated by Philippine NGO, the Institute for Popular Democracy (IPD). This regional project was designed to promote and facilitate political decentralization in four countries, the Philippines, Thailand, Indonesia and Cambodia through such means as promoting democratic participation by local people and people's organizations in local politics, promoting women's political participation and enhancing engagement with local officials, whilst also strengthening the skills and capacity of said officials. A national NGO in each country took responsibility for local initiatives and activities under the leadership of the IPD. There were also regional activities including exchanges to compare effective 
strategies and a regional conference in 2007 comparing methods to promote women's political participation across the four countries.

Within each country activities were developed that were appropriate to the national context. In Thailand, this involved capacity building for local tambon officials, setting up networks for such officials and providing them information to enable them to advocate for political reform. In the rather more conservative environment of Cambodia where decentralization is in its early stages and resources are scarcer, the focus was on activities designed to encourage local people at the grass roots to become politically active through such means as holding civil society consultations on legal changes. There were also commune forums in which local people were able to get assurances from Commune Councils that their interests and views would be taken into account regarding such issues as logging and health. One World Action recorded a number of achievements attributable to the programme inclusive of an Indonesian village in East Bengkulu that won redistribution of its local budget to health and education; the Barangay Council in Manila formalized participation of the urban poor through setting up the Barangay Urban Poor Coordinating Council; and for the first time the Cambodian Government recognized and encouraged civil society recommendations on a new national policy. ${ }^{10}$ This example is indicative of how a Northern NGO might mobilize the local knowledge and expertise of local NGOs (whilst also promoting synergies between them) in order to promote participatory ventures designed to enhance governance goals that benefit local people. Although it is too early to come to firm conclusions on this particular programme it is clear that to the extent it succeeds in delivering benefits local people will have an incentive to sustain its developmental achievements.

Lewis points to the work of the Association of Sarva Seva Farms (ASSEFA) to illustrate that problems as well as benefits can arise out of the participatory approach. ASSEFA was set up to help villagers develop land given to them through the Bhoodan 'land gift' movement. Its field workers took an approach of working with villagers on projects arising out of local people's own initiatives. Although there was evidence that some beneficiaries experienced economic benefit and even enhanced political influence, there were clear difficulties. The ASSEFA field workers often worked with a community for three years before embarking on development activities. Most of the official agencies that many NGOs rely on for finance would never tolerate such a time lapse without production of any development outputs. It is also very difficult for field workers to judge when a group is ready to become independent and so there is a tendency for NGOs to maintain their support for groups too long. Consequently, they tended to stifle rather than build the local capacity that would help to bring about sustainability. There were also some instances where NGO activities prompted a level of political consciousness that led to conflict and violence, which raised questions about the legitimacy of such activities and also put any economic gains that had been made in jeopardy. ${ }^{11}$

It must also be noted that the image of the participatory NGO manned by a value driven work force that uses local knowledge to ensure that its projects are relevant to local needs represents a far from universal stereotype. There are many NGOs that are just as hierarchical and bureaucratically rigid as the official agencies. Similarly, many NGOs do not subscribe to the participatory ideal and work in the traditional top-down manner through which projects are identified and designed by 
experts from outside the beneficiary community, often with minimal input from the latter. Rather than having intimate links with people at the grass roots some NGOs are run by members of the elite and their programmes and projects are prone to cooptation by local members of the elite. Clearly such NGOs have no advantage over official agencies in achieving sustainable development, nor can they claim legitimacy as representatives of excluded elements of civil society.

Another factor that can militate against NGO effectiveness and independence concerns the question of how they finance their activities. Van de Walle points out that in 1980, funding from international donors "accounted for less than 10 percent of NGO budgets, [but] by the 1990s their share had risen to 35 percent." 12 As Robbins puts it: ${ }^{13}$

There is plenty of evidence that the growth in size and number of NGOs is fed by increased governmental contributions along with greater contributions from multilateral developmental organizations such as the World Bank. On the one hand, these conditions have created additional monies for NGOs and GROs [Grassroots Organizations] to develop; on the other hand, they risk becoming so dependent on governments that they have been coopted and their independence threatened.

Whilst funding from Northern aid donors can enable NGOs to engage in development interventions that might otherwise be impossible, there is always the danger of NGO independence being compromised. Johnson argues that "the need to maintain funding may create a situation in which projects are designed in a way that reflects the needs and preferences of donors, not beneficiaries." 14 As we shall see the issue of finance can be a major factor in determining how effectively NGOs can work for both the dimensions of sustainability dealt with here.

Indeed, some commentators are actively hostile to NGOs viewing them as representatives of foreign interests and perhaps even as the bearers of a new imperialism through which the North is exerting its influence over the Global South. This hostility and suspicion is shared by some countries in the Asia Pacific region. Until recently, Burma puts limits on the free movement of NGOs about the country, even insisting that NGO personnel had to get permission to travel to affected areas after Cyclone Nargis in 2008. ${ }^{15}$ Similarly, governmental suspicion of NGOs led several states to intervene in the process of selecting civil society representatives to speak about human rights issues at the fifteenth ASEAN Summit in 2009. Debbie Stothard, coordinator for Alternative Network for Asean on Burma commented that the Asean leaders' unwillingness to have a dialogue with NGOs shows the "'negative mentality of the Asean elites."16

If some Asia-Pacific states are suspicious of what they see as the alien governance and human rights agendas that they associate with NGOs, other commentators are suspicious of the NGO role in promulgating foreign economic agendas. It has been argued that NGOs play a prominent role in promoting the neoliberal marketisation agenda favoured by the major official aid donors including the US, the World Bank and the IMF. It is well known that the development strategies sponsored by these organizations involve some measures that have deleterious effects 
on living standards not only for the poor, but also for the middle classes. Structural adjustment programmes (and the successor Poverty Reduction Strategy Papers) involving such measures as state retrenchment can cause unemployment; cuts in state spending on education and health also have painful social effects and reduction of state subsidies together with devaluations raise living costs across the board. Such policies have caused significant popular protest across the Global South inclusive of the Asia-Pacific region. It has been argued that NGOs facilitate the spread of these marketisation policies by acting as a palliative against their worst effects. By stepping in to provide services that governments, have divested themselves of and by mitigating the impoverishment caused by such policies as withdrawal of subsidies NGOs help to reduce popular opposition to neo-liberal policies. This NGO role of smoothing the path for adoption of free market policies might not be seen as entirely helpful or appropriate given that a number of countries in the Asia-Pacific and East Asian regions have attained considerable economic success through mixed economy approaches that accorded the state a central role in economic management.

This issue is exacerbated by the fact that whilst many NGOs function as effective service providers, others are ill equipped to serve this role. They lack the resources to take over government services and deliver them effectively and Lewis notes "many examples of NGO service provision being characterized by problems of quality control, limited sustainability, poor coordination and general amateurism.",17 A case study of NGOs in the Pacific concluded that: ${ }^{18}$

Given the retrenchment in the public sector resulting from the implementation of structural adjustment programmes, the role of NGOs in service delivery has become ever more critical. Pacific Island Governments are also coming to depend on NGOs to deliver essential public services... However, NGOs and CBOs are often under-resourced and finding it difficult to meet the increasing demands being placed on them by donors, Pacific Island governments and the needs of the communities they serve.

Clearly sustainability of development interventions is not best served by transferring services from the state to under-resourced NGOs.

What does this mean for NGO capacity to fulfill the first dimension of sustainable development? There certainly are some NGOs that have the capability to design and implement interventions that deliver lasting benefits to communities in the region as the example of the CPLG Programme indicates. However, NGOs cannot be regarded as a homogenous group of participatory institutions with universal expertise in working at the grass roots and mobilizing local communities behind development. Much depends on such variables as their sources of funding, the reliability of those sources, the associated policy commitments such funding brings with it, not to mention the internal structure of the NGO, the commitments and capacities of its personnel and how close its relations are with communities at the grass roots. The difficulties that reform orientated NGOs have had with certain regimes such as that of Burma and the leadership of ASEAN are indicative that sustainable progress is contingent on the relationships NGOs are able to maintain with states in the region. Clearly if this relationship becomes overtly hostile certain states in the region may endeavour to exclude NGOs from the policy process. As we shall see, relations with 
the state are particularly salient with regard to the second dimension of sustainable development, preservation of the environment.

\section{THE ENVIRONMENTAL DIMENSION OF SUSTAINABILITY}

Over the last two decades there has been a tendency for NGOs to become more involved in advocacy activities as well as, or instead of service delivery and project implementation. As the number of Southern NGOs providing services has grown, many Northern NGOs have sought to develop a new advocacy role. Rugendyke follows Anderson and Eade to define advocacy as follows: ${ }^{19}$

The term 'advocacy' is generally used by NGOs to refer to campaigning, which involves attempts to change public opinion, and lobbying, which aims to change 'structures, policies and practices that institutionalize poverty and related injustice' ...Campaigning encourages public support for lobbying activities, so, in essence, both attempt to influence policy formation as a means of facilitating positive change in people's lives. While there is a diversity of approaches to advocacy, it is 'self-evidently of a political nature (both in itself and in terms of what it seeks to achieve).

There have been numerous instances of NGOs campaigning to raise public support for change whilst also lobbying governments and institutions such as the World Bank. Some of them have attained at least some measure of success. Probably one of the best-known examples is the Make Poverty History campaign in which numerous NGOs, charities and faith organizations successfully allied themselves to put global poverty on the agenda at the G8 meeting at Gleneagles in 2005.

Environmental sustainability has also been the subject of much advocacy work by NGOs both nationally and internationally. In this section we shall examine how far NGO advocacy has helped achieve the goal of environmental sustainability in the Asia-Pacific. NGO campaigns have been instrumental in bringing about change in the World Bank's policies in such areas as energy, forestry and involuntary resettlement related to major infrastructural projects. ${ }^{20}$ Indeed, NGO environmental campaigns have impacted on World Bank projects in the Asia-Pacific region, notably the Arun Dam in Nepal, which was proposed for funding in 1993. A Nepalese NGO representing residents of the Arun River valley, the Arun Concerned Group filed a complaint with the Bank's Independent Inspection Panel arguing that the Bank had taken insufficient account of environmental damage and damaging effects on indigenous people in the area. The Panel found that the Bank had failed to observe its own policies whilst preparing the project and as a result the Bank withdrew its support. $^{21}$

It could well be argued that the region is in dire need of some effective advocacy to salvage a badly damaged environment. According to the Asian Development Bank (ADB), Asia is now the dirtiest continent on Earth, with widespread and serious water and air pollution, together with problems like deforestation and serious loss of biodiversity. ${ }^{22}$ This has not gone unrecognized and there has been an explosion of environmental NGOs being set up throughout the 
region. Frank et al note that "in virtually every Asian country, there is a long list of domestic environmental NGOs - entities that range in size and permanence from tiny fledgling grass-roots coalitions to longer established, better funded, and technically sophisticated formal organizations." ${ }^{23}$ However, as we have seen, Asia-Pacific governments and the ADB can be resistant to NGO campaigns on sensitive issues such as human rights. This is a particularly important issue given that development of a cooperative relationship with the target of lobbying is often identified as one of the conditions for successful advocacy. Other criteria for success include avoidance of cooptation by the advocacy target, thus entailing an NGO walking a careful line between cooptation and cooperation; building an effective alliance, both domestically and internationally; having clear objectives; being capable of persistent action over a period of time; and having a claim to accountability in the sense of representing a domestic constituency or the national interest. ${ }^{24}$ How then do environmental NGOs in the Asia-Pacific pursue their aims and with what success?

Evidence that NGOs have used advocacy effectively in the region can be drawn from the example of a prominent campaign of the 1990s and the first years of the new century, which concerned the Theun-Hinboun Dam in Laos. This hydropower project was designed to enhance foreign exchange revenues for the Lao Government by selling electricity to Thailand. The dam was vigorously backed by the ADB, which claimed that it was a model project with negligible adverse effects on local residents or the environment. The project involved diversion of water from the Theun-Hading River into the Hai and Hinboun Rivers, causing notable changes to the natural river flow. This, together with disquiet about ADB planning procedures, prompted NGO concern that led to a substantial advocacy campaign. The NGOs involved included the International Rivers Network (IRN), an American NGO with a remit of protecting rivers across the world; Mekong Watch, a Japanese aid-monitoring NGO; Oxfam Community Aid Abroad from Australia; Probe International of Canada; World Wildlife Fund, Thailand; and Towards Ecological Recovery and Regional Alliance (TERRA) also from Thailand.

One difficulty for the NGO campaign was posed by the centralist nature of the Laotian regime, which proscribed domestic NGOs and denied local residents any legal recourse against government action. This made it problematic for the campaign to claim that it was representing any domestic Laotian constituency, thus casting some doubt on its accountability. The NGOs endeavoured to counteract this by undertaking extensive research on the ground, which demonstrated that even in the earliest stages of the project the changes in the flow of the river were damaging livelihoods in local communities due to such effects as erosion, damage to river banks and changes to fish migration. The ADB's initial response was one of denial, even exercising pressure against local residents who had been quoted in the NGO's reports to withdraw their statements.

However, the NGO's maintained pressure on the ADB through lobbying activities and by linking up with more general campaigns to reform the working of the Bank. In 2000, the ADB and the Theun-Hinboun Power Company (THPC) the private operators of the dam agreed a mitigation and compensation programme (MPC) for those adversely affected by the project. There was even an agreement that THPC and IRN should collaborate on a review of the project. Despite finding that the MPC was working quite well this joint review broke down over arguments as to its 
coverage. Whereas THPC wanted only to review the working of the MPC, the IRN wanted to evaluate the project as a whole with a view to demonstrating irreversible environmental damage. Whilst many NGOs remained discontented about the environmental aspects of the project it was clear that the advocacy campaign had achieved some notable gains. The MPC was apparently effective and the IRN argued that there had been beneficial effects on the ADB: ${ }^{25}$

(T)here have been improvements in Bank practice...Diligence on projects is more than it used to be... They are definitely a lot more careful about what they do...[and] if there hadn't been campaigns and pressure on the Bank's support for hydropower in the Mekong there probably would have been more dams.

This suggests that environmental advocacy can be effective even when it concerns some of the more closed regimes in the Asia-Pacific region.

It can be seen that the Theun-Hinoun Dam advocacy campaign met some of the conditions that observers have identified for advocacy success, but not others. Most notably the Laotian political system made it nearly impossible for the campaign to directly represent local people affected by the dam. Focusing lobbying on the ADB, which was subject to pressure from donor governments, evidently compensated this. As Soutar notes, "donor governments based in Northern countries are theoretically answerable to their own taxpayers and could be pressured to in turn pressure the bank to take action." 26

This approach, combined with effective linkage to other advocacy campaigns addressed to the Bank and a scrupulously thorough approach to research into the situation on the ground, gave the Theun-Hinboun campaign sufficient impetus to win substantive changes in a major project despite the aforementioned problem of representation.

If advocacy can bear some fruit in these relatively unpromising conditions it might be asked if environmental NGOs can be effective in China, the largest state in the region, also traditionally a centralist regime and arguably the country with the most extensive environmental problems. It is well known that China has achieved enormous economic growth in recent decades, but this success has been at tremendous environmental cost. In 2001, the World Bank reported that sixteen of the twenty most polluted cities in the world are in China. Air pollution is thought to be responsible for 300,000 premature deaths per year, use of solid fuels especially in rural homes leads to about 420,000 premature deaths annually, the soil is increasingly polluted with heavy metals and out of 200 major rivers, water quality in 20.8 percent of 409 monitored sections was below grade $\mathrm{V}$, the worst grade in the Chinese National Standard for Water Quality. ${ }^{27}$ Deforestation and desertification are also increasing problems, with about one-quarter of the country consisting of desert. ${ }^{28}$

These developments have prompted increasing concern not only at the state level but at various levels in society and one indication of this has been the proliferation of environmental NGOs (ENGO). Since the founding of the first Chinese ENGO in 1994, Friends of Nature, hundreds of organisations have been set up operating in various sectors including "environmental education, nature conservation, 
species protection and legal advocacy." 29 In 1994, there were nine ENGOs, including four student organizations, but in 2001, there were 184 student environmental organizations and 73 non-student ENGOs by $2002 .{ }^{30}$ NGOs are now thought to number in the thousands.

The state was careful to exert control over the growth of this emergent ENGO sector. Jiang Ru described the regulatory measures as follows: ${ }^{31}$

The Chinese State has developed a vigorous set of NGO regulations to control the development and activities of NGOs. Three key control measures of these regulations are:

- An NGO has to be registered at a civil affairs office according to its geographic scope of activities;

- An NGO has to find a supervisory organization to sponsor its registration with a civil affairs office. Here, a supervisory organization, referred to as a "mother-in-law organization" by some scholars, is a state-authorized organization that sponsors an NGO's registration application to a civil affairs office, and then supervises the NGO's activities after the NGO registers with the civil affairs office; and

- Civil affairs offices will force NGOs to correct any violations of above-noted and other NGO control measures.

This level of regulation has prompted many analysts to argue that China does not have NGOs proper, but has Government Organised NGOs (GONGOs). However, as we shall see, not all ENGOs in China conform to these regulations.

Jiang $\mathrm{Ru}$ has argued that despite government regulation "environmental activists were able to create NGOs and operate with a fair amount of freedom by selfcensoring the activities of their NGOs." ${ }^{32} \mathrm{He}$ also found that Chinese civil authorities tended to be tolerant of NGOs so long as they posed no political threat and refrained from engaging in financial impropriety. Indeed, the authorities had insufficient resources to track all NGOs and a number of organizations were set up without going through the registration process. These were allowed to operate without government interference provided they did nothing deemed politically threatening. ${ }^{33}$ Economy argues that this context enabled ENGOs to become more assertive over a period of time. Whilst the first ENGOs engaged in relatively uncontroversial areas such as environmental education and biodiversity protection, later ENGOs were more willing to address politically sensitive issues. Economy points to the example of the Go West campaign of 1999, which targeted development of Western China to enable it to catch up with the coastal regions. Environmental protection was identified as a central tenet of the campaign, but various ENGOs were concerned that in reality this aim would come a poor second to promotion of economic growth. They were also worried that funds would be siphoned off from environmental protection due to corruption. Consequently there was quite vigorous ENGO lobbying to ensure that the State Environment Protection Administration (SEPA) was included in the group of agencies tasked with leading the Go West campaign. This proved to be a successful 
instance of ENGO advocacy in China. There were further successes including an unprecedented government decision of January 2005 to stop thirty large infrastructural projects because environmental impact assessments had not been done. However, Economy notes that all of these successes were achieved with the approval of SEPA and Premier Wen Jiabao. ${ }^{34}$ This suggests that advocacy is more likely to be successful if the NGO campaigners develop a cooperative relationship with the advocacy target. By the same token it is worth remembering that if NGOs are to make a real impact in attaining their goals they need to avoid cooptation by the state or other institutions.

It is nevertheless clear that a number of successes can be attributed to China's ENGOs. One such is the Environmental Educator's Initiative (EEI) set up in 1997 by the World Wide Fund for Nature (WWF) China to incorporate education on environmental sustainability into China's educational curriculum. The EEI's activities include "teacher education, resource development, and establishment of a number of regional environmental education centres" as well as support for "a number of pilot schools that act as leaders and developers of environmental education innovation and change." 35 A cooperative approach to the Ministry of Education helped ensure project success in influencing government to incorporate sustainability into the national curriculum.

The Centre for Legal Assistance to Pollution Victims (CLAPV) founded by Weng Canfa in 1998 also represents a significant initiative, the aim of which is to provide legal redress for victims of industrial pollution. The CLAPV operates a hotline that takes numerous phone calls on legal questions concerning the environment. By 2007, the CLAPV had given legal aid for 98 cases, 35 of them involving damage to human health. Xu Kezhu, the deputy director of CLAPV pointed out that although they had only won twelve of those 35 cases there had been some beneficial results for the plaintiffs even in a number of the cases that had been lost. This was because local governments and industries were influenced to improve conditions for the pollution victims. Deputy Director Kezhu also noted that CLAPV seemed to be influencing the general populace in that more people who were adversely affected by environmental pollution were turning to law in the hope of obtaining redress. ${ }^{36}$

Whilst it is clear that there are numerous ENGOs in China that have contributed to environmental improvement the question arises as to how they can have any substantial impact given the sheer scale of China's environmental problems. Admirable as the CLAPV is it cannot hope to address the full scale of industrial pollution in China. It also seems likely that the non-confrontational and cooperative approach to advocacy that typifies Chinese ENGOs is unlikely to motivate the Chinese Government to put environmental considerations before the priority of economic growth.

This view is confirmed by the indecisive outcome of the UN Climate Change Conference held in Tianjin, north China in October 2010. The conference was meant to pave the way for the Cancun Conference scheduled for late 2010, which is supposed to give shape to the successor regime for the Kyoto Protocol, inclusive of setting targets for reduction of greenhouse gas emissions. This process has been the subject of vigorous ENGO lobbying from across the world, the essential objective 
being to establish a regime that would preserve the global environment whilst allowing the Global South sufficient leeway to pursue their development strategies. The outcome of the Tianjin Conference suggests that the efforts of the international NGO lobby have been without effect. The conference developed into an all too familiar pattern of a stand-off between the two main greenhouse gas emitters, China and the USA, with each one insisting that the other had to give more ground before they would commit to a new regime for emissions cuts to replace the Kyoto Protocol. Whilst most international ENGOs focused their ire on the rich countries including the USA, arguing that they were backtracking on their commitments, the outcome at Tianjin also indicates that the Chinese Government's commitment to economic growth outweighs its concern for the environment. This is suggestive that for all its achievements the Chinese ENGO sector has some way to go before it makes decisive inroads into this situation. ${ }^{37}$

The potential vulnerability of the ENGO sector in China is illustrated by Yang who notes that a substantial proportion of financing for them comes from the international NGO sector. He notes that from 1996-99, "85 per cent of the funding for the Global Village of Beijing came from INGOs and foreign governments while the domestic private sector contributed only 10 per cent." Similarly, the funding for major NGOs such as Friends of Nature and The Centre for Biodiversity and Indigenous Knowledge received most of their funding from foreign sources. Even some small NGOs have been given INGO funding. ${ }^{38}$ Indeed, Parks has pointed out that this is the case in many countries in the Asia-Pacific. He notes that foreign donors were eager to support civil society in the 1990s and this translated into finance for domestic NGOs. The result was an NGO boom in certain countries like the Philippines where the number of NGOs grew from 27,000 in 1986 to at least 60,000 by $1999 .{ }^{39}$ The problem is that donor funding is not consistent or reliable and it did indeed fall from the late 1990s at which point the NGO sector in countries like Cambodia and the Philippines went into decline. Thailand experienced a similar cycle of boom in donor funding followed by decline, but the NGO sector was slightly better equipped to deal with it because alternative domestic sources of finance emerged, whereas local funding was low to non-existent in the Philippines and Cambodia. ${ }^{40}$ Given China's level of development it should be better equipped than Thailand to develop private sources of NGO funding, this certainly being a view shared by Bill Gates and Warren Buffett who visited China in September 2010 with a view to promoting private philanthropy amongst the Chinese nouveau riche. Unfortunately, Chinese law does not favour NGO ability to exploit this potential funding source because only government registered NGOs are allowed to raise money publicly and this does not include the majority of unregistered grass roots NGOs. ${ }^{41}$

This brief survey indicates that NGOs can definitely make a contribution to environmental sustainability both through projects such as WWF China's Environmental Educator's Initiative and through advocacy campaigns such as that concerning the Theun-Hinboun Dam. However, the extent of environmental problems throughout the Asia-Pacific region and particularly in China is indicative that it would be wrong to look to NGOs as the salvation of the environment in the region. The limited resources available to NGOs are insufficient to enable them to make the necessary impact. Any effective strategy for enhancing environmental sustainability will have to be the result of an alliance involving not only NGOs, but also international actors such as the United Nations, the state and civil society. Notably, 
such a strategy would have to change attitudes amongst the businesses that are responsible for much environmental damage. Clearly, there is some distance to go before the state and the business sector are brought fully on board in the cause of environmental sustainability. The ENGO sector is attempting to play an important strategic role in winning their support for this cause through advocacy and other activities.

\section{CONCLUSION}

We have seen that NGOs can indeed play an important if not crucial role in developmental and environmental sustainability in the Asia-Pacific region. However, whilst they may be important to the achievement of these two dimensions of sustainability, NGO activity is not sufficient on its own to deal with the development and environmental problems to be found in the region. Such problems are so extensive that they will require a broadly based alliance to deal with them, involving not only NGOs, but the state, civil society, business and international actors. The critical role that NGOs can play is to demonstrate through their activities and campaigns how all these parties can benefit through cooperation towards environmental and developmental sustainability.

The examples cited in this paper illustrate that NGOs can develop the capacity to mount effective environmental advocacy campaigns and many have demonstrated the ability to deliver sustainable development to local communities. The fact that they have been able to do so even in states that are suspicious of NGOs, if not actively hostile to them is a cause for optimism. It indicates that they have real potential to demonstrate the benefits of environmental and developmental sustainability and thus provide a focal point for an alliance to achieve such aims. Whilst NGOs may not be the whole answer they have the potential to be a significant part of the answer to the Asia-Pacific region's problems of sustainable development.

\section{NOTES}

${ }^{1}$ Johnson Wagona Makoba, "Nongovernmental organizations (NGOs) and Third World Development: An Alternative Approach to Development," Journal of Third World Studies, Vol. 19, No. 1, Spring 2002, pp. 53-63.

${ }^{2}$ Padraig Carmody, Neoliberalism, Civil Society and Security in Africa, Hampshire: Palgrave MacMillan, 2007, p. 24.

3 Quoted in Thalif Deen, "U.N. Blasted for Sequestering Ngos and Media," <www.globalissues.org/news/2010/04/16/5251>

${ }^{4}$ David Harvey, A Brief History of Neoliberalism, Oxford: Oxford University Press, 2005, p. 177.

${ }^{5}$ John D. Clark, "NGOs and the State," in Vandana Desai and Robert B. Potter (eds.), The Companion to Development Studies, London: Arnold, 2002, p. 495.

${ }^{6}$ Jan Nederveen Pieterse, Development Theory, London: Sage, 2001, p. 75.

7 Anup Shah, "Non-governmental Organizations on Development Issues," <www.globalissues.org/article/25/non-governmental-organizations-on-development-issues>

${ }^{8}$ For a discussion of NGOs efficacy as development agents see David Lewis, The Management of Non-Governmental Development Organization, Oxford: Routledge, 2001, particularly chapter 3 . 
${ }^{9}$ John Farrington and David J. Lewis with S. Satish and Aurea Michat-Teves, NonGovernmental Organizations and the State in Asia: Rethinking Roles in Sustainable Agricultural Development, Oxford: Routledge, 1993, p. 6.

${ }^{10}$ All details of the CLPG Programme from One World Action, Citizen's Participation and Local Governance in South East Asia, 2002.

${ }^{11}$ Lewis, The Management of Non-Governmental Development Organizations, pp. 78-79.

${ }^{12}$ Nicolas Van de Walle, "Aids Crisis of Legitimacy: Current Proposals and Future Prospects," African Affairs, Vol. 98, 1999, p. 345.

${ }^{13}$ Richard Robbins, Global Problems and the Culture of Capitalism, Boston: Allyn and Bacon, 2002, p. 129.

${ }^{14}$ Craig Johnson, "Towards Accountability: Narrowing the Gap between NGO Priorities and Local Realities in Thailand," Working Paper 149, London: Overseas Development Institute, 2001.

${ }^{15}$ U.S. Department of State, "Human Rights Report 2009," Washington, D.C.: Department of State, United States, <www.state.gov/g/drl/rls/hrrpt/2008/eap/119035.htm>

16 "A difficult birth for Asean human rights," Bangkok Post, 25 October 2009.

${ }^{17}$ Lewis, The Management of Non-Governmental Development Organizations, p. 114.

${ }^{18}$ Will Low and Eileen Davenport, "NGO capacity building and sustainability in the Pacific," Asia Pacific Viewpoint, Vol. 43, No. 3, December 2002, p. 377.

${ }^{19}$ Barbara Rugendyke, "Lilliputians or leviathans? NGOs as Advocates," in Barabara Rugendyke (ed.), NGOs as Advocates for Development in a Globalising World, Oxford: Routledge, 2007, p. 7.

${ }^{20}$ Paul J. Nelson, "The World Bank and NGOs," in Desai and Potter, The Companion to Development Studies, p. 502.

${ }^{21}$ Ibid., p. 501.

${ }^{22}$ David John Frank, Wesley Longhofer and Evan Schofer, "World Society, NGOs and Environmental Policy Reform in Asia," International Journal of Comparative Sociology, Vol. 48, No. 4-5, 2007, pp. 276.

${ }^{23}$ Ibid., p. 276.

${ }^{24}$ See Barbara Rugendyke, "Making poverty history?" in Rugendyke (ed.), NGOs as Advocates for Development in a Globalising World, 2007, pp. 224-9; Thomas Parks, "The Rise and Fall of Donor Funding for Advocacy NGOs: Understanding the Impact," Development in Practice, Vol. 18, No. 2, 2008, p. 218; and Lewis, The Management of NonGovernmental Development Organizations, pp. 124-130.

${ }^{25}$ Quoted in Lindsay Soutar, "Asian Development Bank: NGO encounters and the TheunHinboun Dam, Laos," in Rugendyke (ed.), NGOs as Advocates for Development in a Globalising World, p. 219. For detailed case studies of the Theun-Hinboun Dam, see Ibid., pp. 200-221; and Philip Hirsch, "Advocacy, civil society and the state in the Mekong Region," in Barabara Rugendyke, NGOs as Advocates for Development in a Globalising World, Oxford: Routledge, 2007, pp. 185-199.

${ }^{26}$ Soutar, "Asian Development Bank: NGO encounters and the Theun-Hinboun Dam, Laos," p. 216.

${ }^{27}$ Dutch Trader, "China's Environmental Action Plan: Why China's Environment is Becoming Increasingly Important," <dgriffith401.wordpress.com/2010/07/10/chinasenvironmental-action-plan/>

${ }^{28}$ Elizabeth C. Economy, "Congressional Testimony: China's Environmental Challenges, Council on Foreign Relations," <www.cfr.org/publication/7391/congressional_testimony.html?id=7391>

${ }^{29}$ Guobin Yang, "Environmental NGOs and Institutional Dynamics in China," The China Quarterly, 2005, p. 46. 
${ }^{30}$ Ibid., pp. 50-51.

${ }^{31}$ Roundtable Before The Congressional-Executive Commission On China, "Environmental NGOs in China: Encouraging Action and Addressing Public Grievances," One Hundred Ninth Congress, First Session, 2005, p. 32.

${ }^{32}$ Ibid., p. 6.

${ }^{33}$ Ibid., p. 7.

${ }^{34}$ Ibid., pp. 3-5 and 10.

${ }^{35}$ Daniella Tilbury, Wendy Goldstein and Lisa Ryan, "Towards Environmental Education for Sustainable Development: The Contributions of NGOs in the Asia-Pacific Region," International Review for Environmental Strategies, Vol. 4, No. 1, 2003, p. 134.

${ }^{36}$ See Yang, "Environmental NGOs and Institutional Dynamics in China," p. 53; and Darren Ellis, "Greening the Courts: China's Legal Advocates Giving Voice to Pollution Victims and the Environment," $<$ www.wilsoncenter.org/index.cfm?topic_id=1421\&fuseaction=topics.event_summary\&event $\therefore \mathrm{id}=228068>$

${ }^{37}$ Hiroshi Nagai and Taro Ichikawa, "Tianjin sends out signals of climate hope and scepticism," The Brunei Times, 13 October 2010; and China Climate Change Info-Net, “ Climate talks in Tianjin end with divisions, trust, hope for Cancun," $<$ www.ccchina.gov.cn/en/NewsInfo.asp?NewsId=25743>

${ }^{38}$ Yang, "Environmental NGOs and Institutional Dynamics in China," p. 57.

${ }^{39}$ Parks, "The Rise and Fall of Donor Funding for Advocacy NGOs," pp. 214-5.

${ }^{40}$ Ibid., p. 219.

${ }^{41}$ Shawn Shieh, "Can Warren Buffett and Bill Gates start a philanthropic revolution in China?," <ngochina.blogspot.com/> 